\title{
ARTIKELEN
}

\section{Geloof in de liberale democratie ${ }^{1}$}

\author{
Hans-Martien ten Napel
}

De liberale visie op godsdienstvrijheid vertrekt vanuit een mensvisie waarin het belang van het kunnen beleven van de religieuze identiteit in zowel het publieke als het privédomein vooropstaat. Dit uitgangspunt leidt tot een onderscheidende visie op de plaats van geloof in de liberale democratie, die het voor burgers omgekeerd mogelijk maakt geloof te houden in de liberale democratie. Door deze mensvisie te veronachtzamen lopen nieuwe critici van de godsdienstvrijheid het gevaar de liberale democratie als doel te gaan zien en burgers als middel om dit doel te bereiken. Dit kan op termijn het geloof in de liberale democratie doen verminderen.

\section{Inleiding}

Toen ik in de zomer van 2014 naar de Verenigde Staten vertrok om mij aan een theologisch centrum een academisch jaar lang bezig te houden met het thema godsdienstvrijheid, verwachtte ik dat er sprake zou zijn van een contrast met de wijze waarop in Europa in het algemeen en in Nederland in het bijzonder tegen dit mensenrecht werd aangekeken. Proefde ik hier in sommige gevallen vijandigheid, maar overwegend onverschilligheid jegens het recht, Amerika is het land waar de vrijheid van godsdienst traditioneel als 'First Freedom' wordt aangemerkt. Dit niet alleen omdat het recht is opgenomen in het Eerste Amendement bij de Amerikaanse Grondwet, maar ook omdat brede lagen van de bevolking het beschouwen als het meest fundamentele van alle mensenrechten. Dat heeft te maken met de wordingsgeschiedenis van de Verenigde Staten, waarnaar immers veel Europeanen zijn gemigreerd die in hun vaderland vervolgd werden vanwege hun geloof. In het Eerste Amendement gaat het zelfs niet over de vrijheid van godsdienst en levensovertuiging, zoals in de Nederlandse Grondwet, maar alleen over godsdienst. Zo centraal staat de vrijheid van godsdienst in Amerika, dacht ik.

Direct tijdens het eerste colloquium van de interdisciplinaire onderzoeksgroep van ethici, juristen en theologen waarvan ik deel kwam uit te maken, bleek evenwel ook in de Verenigde Staten een debat op gang te zijn gekomen over de merites van het internationale recht op godsdienstvrijheid in zijn huidige vorm. Een deelnemer aan de wekelijkse discussies was zelf rechtstreeks afkomstig uit een meerjarig internationaal onderzoeksproject over de 'Politics of Religious Freedom', dat

1 Dit artikel is mede geschreven in de context van het NWO-project 'Religion Renegotiated. FaithBased Organizations and the State in the Netherlands Since the 1960s', waarvan de auteur medeaanvrager was. 
inmiddels tot een gelijknamige bundel heeft geleid. ${ }^{2}$ Zoals de titel van project en bundel reeds aangeeft, wordt het hierin voorgesteld alsof in elk geval de internationale godsdienstvrijheid beheerst wordt door politieke intenties en overwegingen. Westerse landen zouden op neokoloniale wijze met behulp van dit instrument hun eigen waarden trachten op te dringen aan andere culturen en religies. Een dergelijk perspectief verschilt onmiskenbaar van de oorspronkelijke Amerikaanse zienswijze, volgens welke de godsdienstvrijheid eerder een natuurrecht is, dat in principe aan eenieder toekomt en voorafgaat aan de staat. De staat heeft vervolgens dit recht te respecteren, of hem dit nu gelegen komt of niet.

In deze bijdrage ga ik verder niet in op de bezwaren van de zogeheten 'new critics of religious freedom' in het algemeen. Zoals te verwachten valt, vormen de critici geen homogene groep, en een enigszins representatieve bespreking van de verschillende naar voren gebrachte punten zou reeds een volledig artikel vergen. ${ }^{3}$ Bovendien waaieren de bezwaren disciplinair gezien nogal uit. In plaats hiervan licht ik er een artikel uit van een auteur die vooral vanuit de invalshoek van het constitutionele recht relevante punten naar voren brengt: Jean L. Cohen, hoogleraar Politieke theorie aan de Universiteit van Columbia in New York. ${ }^{4}$ Cohen doet dit bovendien op degelijke wijze, want goed geïnformeerd over de opvattingen van haar tegenstanders waartegen zij bezwaar maakt. Vervolgens zal ik aangeven waarom de visie van Cohen op geloof in de liberale democratie op gespannen voet staat met een christelijke mensvisie zoals bijvoorbeeld geformuleerd door de Zuid-Afrikaanse emeritus hoogleraar Christelijke ethiek Koos Vorster. Deze visie heeft historisch doorgewerkt in zowel de wijze waarop westerse staten zoals Nederland zijn ingericht, te weten volgens de principes van respectievelijk de rechtsstaat en de democratie, als in de vormgeving van het recht op godsdienstvrijheid. Het artikel sluit af met een korte beschouwing over de reden waarom verwacht mag worden dat van deze laatste wijze van staatsinrichting een grotere aantrekkingskracht zal blijven uitgaan, zowel binnen als buiten de academische wereld, dan van de door Cohen aangehangen variant van liberale democratie. Dit is mede van belang voor de instandhouding van het geloof in de liberale democratie als zodanig.

\section{De kritiek van Jean L. Cohen}

Het is niet mogelijk op deze plaats recht te doen aan het, zoals gezegd, gedegen artikel van Cohen. Voor de doeleinden van deze bijdrage volstaan enkele punten. Het eerste is de concrete aanleiding voor Cohen om haar artikel te schrijven. Deze

2 W.F. Sullivan e.a. (red.), Politics of Religious Freedom, Chicago 2015. Vgl. ook T. Wenger, Religious Freedom: The Contested History of an American Ideal, Chapel Hill 2017.

3 Zie voor een dergelijke poging, met repliek: D. Philpott \& T.S. Shah, 'In Defense of Religious Freedom: New Critics of a Beleaguered Human Right', Journal of Law and Religion 2016, 3, p. 380-395.

4 J.L. Cohen, 'Freedom of Religion, Inc.: Whose Sovereignty?', Netherlands Journal of Legal Philosophy 2015, 3, p.169-210. Zie voorts: J.L. Cohen \& C. Laborde (red.), Religion, Secularism, and Constitutional Democracy, New York 2016. 
wordt gevormd door twee rechtszaken bij het Amerikaanse Hooggerechtshof, die in de periode dat ik in de Verenigde Staten onderzoek verrichtte ook inderdaad de maatschappelijke en wetenschappelijke discussie over het onderwerp godsdienstvrijheid beheersten. De eerste rechtszaak is die van een behoudende evangelischlutherse school, die een lerares ontsloeg omdat zij onvoldoende bij de identiteit van de school zou passen. ${ }^{5}$ In deze zaak, uit 2012, gaat het om het leerstuk dat in de Verenigde Staten bekendstaat als de 'ministerial exception'. In Europa is de doctrine eerder bekend onder de aanduiding 'church autonomy', dat wil zeggen de vrijheid van religieuze organisaties als kerken om bijvoorbeeld een eigen personeelsbeleid te voeren. In bepaalde gevallen ontvangen religieuze instellingen op grond van dit leerstuk inderdaad een vrijstelling van overigens algemeen geldende non-discriminatievoorschriften. Dit geldt in het bijzonder voor voorgangers, vandaar de naam 'ministerial' in de Verenigde Staten. De vraag is echter hoever het begrip 'voorganger' kan en moet worden opgerekt. Het Amerikaanse Hooggerechtshof geeft geen precieze omschrijving, maar stelde toch ook in dit geval de school in het gelijk. De betreffende lerares was immers geen lekenleerkracht, maar kon vanwege de training die zij had ontvangen zelf als geestelijke gelden.

De tweede rechtszaak betreft die van een christelijke onderneming, Hobby Lobby, die zich met een beroep op de vrijheid van godsdienst onttrok aan de door de Obama-regering opgelegde verplichting om aan haar personeel een ziektekostenverzekering aan te bieden waarin tevens anticonceptiemiddelen waren opgenomen. ${ }^{6}$ Ook in deze zaak stelde het Hooggerechtshof de onderneming in het gelijk. Nog meer dan de eerste zaak heeft het Hobby Lobby-arrest een gevoelige zenuw geraakt. In een bekend geworden artikel in de Harvard Law Review sprak de auteur van een 'Hobby Lobby-moment'. ${ }^{7}$ Hij suggereerde daarmee dat deze zaak achteraf wel eens een keerpunt kon blijken te zijn geweest in de publieke opinie over de godsdienstvrijheid. Kon dit recht voorheen op betrekkelijk algemene instemming rekenen in de Amerikaanse samenleving, afgezien van de eerdergenoemde groep van nieuwe critici van de godsdienstvrijheid, een uitspraak ten gunste van een onderneming die zich beroept op een recht dat primair bedoeld is voor individuen tegenover de staat zou slecht begrepen worden.

Dit laatste geldt zeker voor Cohen, die zoals gezegd haar artikel begint met een behandeling van deze beide rechtszaken. In de uitspraken leest zij een wederopleving van een oude, middeleeuwse benadering van religieuze corporaties als zouden deze een bepaalde mate van autonomie of zelfs soevereiniteit bezitten. In een iets moderner jasje valt dit gedachtegoed ook te herleiden tot het Britse, pluralistische denken zoals zich dat rond het begin van de twintigste eeuw manifesteerde. Het is inderdaad al vaker opgemerkt dat de individuele godsdienstvrijheid zoals wij deze thans kennen haar wortels heeft in een meer collectieve vorm van

5 U.S. Supreme Court 2012 (Hosanna-Tabor Evangelical Lutheran Church and School/Equal Employment Opportunity Commission et al), www.supremecourt.gov/opinions/11pdf/10-553. pdf.

6 U.S. Supreme Court 2014 (Burwell, Secretary of Health and Human Services, et al./Hobby Lobby Stores, Inc., et al.), https://www.supremecourt.gov/opinions/13pdf/13-354_olp1.pdf.

$7 \quad$ P. Horwitz, 'The Hobby Lobby Moment', Harvard Law Review 2014, 1, p. 154-189. 
godsdienstvrijheid zoals deze tijdens de late Middeleeuwen ontstond. Dit laatste idee staat bekend als dat van 'freedom of the church'. ${ }^{8}$ Ook is er in later tijd een pluralistische school van denken over de staat geweest die deels teruggreep op dergelijke noties. Nog recentere stromingen als het liberale pluralisme, waartoe bijvoorbeeld William A. Galston behoort, ${ }^{9}$ grepen op hun beurt weer terug op dit Britse, pluralistische denken.

Cohen heeft moeite met deze denkrichting. Zij meent dat rechterlijke uitspraken als hiervoor genoemd eerder een bedreiging vormen voor dan een uitbreiding zijn van de vrijheid, de democratische legitimiteit en de vorm van pluralisme die een liberale democratie volgens haar dienen te kenmerken. In het kort komt haar kritiek erop neer dat we een terugkeer meemaken van een liberaal constitutionele benadering die vragen als die over de evangelisch-lutherse school en de christelijke onderneming inmiddels gewoon was te behandelen in termen van rechtvaardigheid, naar een benadering die deze weer opvat in termen van bevoegdheid van levensbeschouwelijke organisaties tegenover de staat. Zij spreekt van een opvatting als zouden deze organisaties over een eigen jurisdictie beschikken, die hen ten onrechte immuun maakt voor bepaalde door de staat uitgevaardigde regelgeving. Vervolgens komt zij tot de terechte vaststelling dat een en ander voortkomt uit een politiek-theologische visie op de waarde van instituties en ook van soevereiniteit. Het is voor onderzoekers op het terrein van recht en religie soms noodzakelijk om de theologische achtergronden van bepaalde regels, of zoals in dit geval de uitzondering op dergelijke regels, in de beschouwing te betrekken.

Hoewel zelf niet theologisch geschoold of geëngageerd, geeft Cohen er blijk van dit goed te begrijpen. De collectieve dimensie van godsdienstvrijheid heeft haar wortels in de strijd tussen pausen en vorsten in de elfde en twaalfde eeuw over de vraag wie het recht had hoge geestelijken te benoemen.

In de beleving van Cohen leidt de hedendaagse variant van deze theologisch-politieke visie tot ongerechtvaardigde privileges van religieuze instellingen, zoals de behoudende evangelisch-lutherse school, en zelfs bedrijven. Deze kunnen zich bijgevolg onttrekken aan juridische verplichtingen. Dat is voor Cohen geen kwestie van eerlijke of gelijke behandeling, maar een inbreuk op hoe liberale rechten in de praktijk behoren uit te werken. Daarmee levert de theologisch-politieke opvatting volgens haar een bedreiging van democratisch-rechtsstatelijke verworvenheden op. Het maakt het er voor Cohen begrijpelijkerwijze niet beter op dat die situatie zich niet tot de Verenigde Staten beperkt. Hoewel zij begon met het behandelen van twee Amerikaanse arresten, worden dezelfde argumentaties wereldwijd gebruikt onder de noemer van de 'vrijheid van godsdienst'. Dit levert potentieel bijvoorbeeld ook een risico op voor Nederland, waar Cohen de lezing gaf waarop haar in deze paragraaf besproken artikel is gebaseerd.

8 Zie bijv. R.W. Garnett, “The Freedom of the Church”: (Towards) an Exposition, Translation, and Defense', Journal of Contemporary Legal Issues 2013, p. 33-57.

9 W.A. Galston, Liberal Pluralism. The Implications of Value Pluralism for Political Theory and Practice, Cambridge 2002; W.A. Galston, The Practice of Liberal Pluralism, Cambridge 2005. 
Zoals duidelijk mag zijn, kwalificeert Cohen zich met haar kritiek op de vrijheid van religieuze organisaties om bijvoorbeeld een eigen personeelsbeleid te voeren als 'new critic of religious freedom'. Maar beperkt de kritiek van Cohen zich eigenlijk nog wel tot de godsdienstvrijheid of gaat het haar in de kern om een bepaald ideaal van liberale democratie? Naar mijn oordeel is dit laatste het geval.

\section{De rol van antropologie}

Hoewel ik, zoals hierna zal blijken, hun kritiek niet deel, ben ik de 'new critics of religious freedom' erkentelijk omdat zij mij het thema hebben aangereikt voor het boek dat ik naar aanleiding van mijn verblijf in de Verenigde Staten schreef. ${ }^{10}$ Dit gaat niet alleen over godsdienstvrijheid, maar over de relatie tussen dit mensenrecht en de uitgangspunten van constitutionalisme en democratie zoals deze ten grondslag liggen aan westerse politieke stelsels. De ondertitel, To Be Fully Human, is van wezenlijk belang. Deze was oorspronkelijk bedoeld als hoofdtitel, maar de uitgever maakte zich begrijpelijkerwijze zorgen of zo'n hoofdtitel wel voldoende duidelijk zou zijn. Toch drukt de ondertitel iets wezenlijks uit, want achter het verschil van inzicht met Cohen over de plaats van geloof in de liberale democratie gaat een verschil in mensvisie schuil. Wie nadenkt over de vraag hoe de staat het beste kan worden ingericht, zal zich eerst dienen af te vragen wie de mens is. Kenmerkend voor westerse staten is immers, als het goed is, dat de staatsinrichting in dienst staat van de mens en niet andersom.

Hoe vanzelfsprekend dit wellicht ook klinkt, het verwarrende is dat uit de kritiek van Cohen op het leerstuk van de 'freedom of the church' een staatsvisie spreekt die dat belangrijke inzicht uit het oog lijkt te zijn verloren. De indruk die men bij kennisname van haar kritiek krijgt, is dat Cohen er een inhoudelijk ideaal van liberale democratie op nahoudt. Dit ideaal wordt beheerst door opvattingen over democratische soevereiniteit, liberaal constitutionalisme, rechtvaardigheid, pluralisme en rechten. Wat opvalt, is dat dit rijtje niet wezenlijk verschilt van hetgeen de voorstanders van de actuele uitleg van het recht op vrijheid van godsdienst en levensovertuiging door onder meer het Amerikaanse Hooggerechtshof voorstaan. Het verschil zit in een andere interpretatie die Cohen erop nahoudt van deze elementen. Meer in het bijzonder staan de elementen van pluralisme en rechten bij haar in dienst van die van democratische soevereiniteit en liberaal constitutionalisme. Dat betekent dat voor Cohen de uitoefening van liberale rechten zich moet blijven bewegen binnen de grenzen van een meerderheidsconsensus die op democratische wijze tot stand is gekomen. Evenmin zal het gewenste pluralisme in de samenleving afbreuk mogen doen aan datgene waar het liberale constitutionalisme in haar optiek voor staat. Voor zover er door minderheden argumentaties worden gebruikt die hiermee schuren, zullen deze moeten wijken, ongeacht of dat nu het geval is in de Verenigde Staten of bijvoorbeeld in Nederland. 
Ik zal hier geen poging ondernemen de mensvisie te expliciteren van waaruit Cohen meer of minder stilzwijgend werkt. In plaats daarvan geef ik in het kort de mensvisie weer waaraan de ondertitel van mijn boek, To Be Fully Human, is ontleend. Het citaat uit deze titel is afkomstig uit een artikel van de Zuid-Afrikaanse emeritus hoogleraar Christelijke ethiek Koos Vorster. Reeds in de aanloop naar mijn verblijf in de Verenigde Staten trof mij de volgende passage uit dit artikel:

'The attitude of the Christian towards other religions can be served best where room is created for all to be fully human in the public and private spheres. To be fully human means to cradle the spirituality of one's religion and to build one's life on the foundation that the religion offers. ${ }^{11}$

Wat allereerst opvalt is dat het voor een ethicus kennelijk natuurlijker is om, schrijvend over geloof in de liberale democratie, de vraag naar de antropologie te stellen. Cohen doet dit in haar artikel niet, met als gevolg dat de lezer de mensvisie van waaruit zij werkt zelf moet trachten te reconstrueren. Voor veel andere juristen en politieke theoretici geldt hetzelfde, terwijl het toch niet goed mogelijk is het recht of de staat te bestuderen zonder daarbij een bepaalde mensvisie als uitgangspunt te nemen.

Wat betreft de inhoud van de door Vorster gepresenteerde mensvisie licht ik hier het onderscheid tussen het publieke en het privédomein eruit. Sommige nieuwe critici van het recht op godsdienstvrijheid zullen dit een concessie vinden aan het liberalisme, in de zin dat het onderscheid in een publiek en een privédomein zelf ontleend is aan het liberalisme en het idee achter liberale rechten. Hiermee wordt voorbijgegaan aan de invloed die het christendom op het liberalisme heeft uitgeoefend, in de zin dat het onderscheid tussen twee rijken diepe christelijke theologische wortels heeft in het werk van bijvoorbeeld Augustinus en Luther en uiteindelijk in uitspraken van Jezus in het Nieuwe Testament over het geven aan de keizer wat de keizer toekomt en aan God wat God toekomt. ${ }^{12}$ Wat hier verder van zij, het is interessant dat Vorster in het hiervoor gegeven citaat zowel poogt recht te doen aan dit onderscheid tussen het publieke en het privédomein als tegelijkertijd de kloof tussen beide tracht te overbruggen. Voor hem is de essentie van het mens-zijn immers gelegen in het inrichten van ieders leven op het fundament van een geloof en dat ruimte moet worden gegeven, niet alleen door christenen maar ook door de staat, om dit zowel in het publieke als in het privédomein te doen.

De vraag die het citaat opwerpt, is wat het onderscheid tussen het publieke en het privédomein precies inhoudt en hoe en waar de grens moet worden getrokken. Voor het doel van dit artikel volstaat het hiervoor te verwijzen naar de veelheid

11 J.M. Vorster \& J.M., 'Current Options for the Constitutional Implementation of Religious Freedom', in: A. van de Beek, E.A.J.G. Van der Borght \& B.P. Vermeulen (red.), Freedom of Religion, Leiden/Boston 2010, p. 155-179, aldaar p. 179.

12 Cf. M.W. McConnell, 'Old Liberalism, New Liberalism, and People of Faith', in: M.W. McConnell, R.F. Cochran, Jr. \&A.C. Carmella (red.), Christian Perspectives of Legal Thought, New Haven 2001, p. 5-24. 
aan levensbeschouwelijke organisaties die zeker ook in Nederland vanouds door burgers zijn gevormd en daarmee intermediaire verbanden vormen tussen deze burgers en de staat. Tegen deze achtergrond bezien kan het publieke domein worden omschreven als omvattend de activiteit die burgers ontplooien in het verband van levensbeschouwelijke organisaties teneinde handen en voeten te geven aan hun geloof of levensovertuiging. Volgens Vorster is het nu van belang dat de staat voluit ruimte schept voor een dergelijke activiteit van burgers, naast de godsdienstvrijheid die zij in de privésfeer dienen te genieten.

We kunnen al met al constateren dat Vorster op een andere manier redeneert dan Cohen. We zagen hiervoor dat Cohen begint te redeneren vanuit haar ideaal van wat een liberale democratie moet inhouden. Mensen en hun organisaties moeten er vervolgens op toezien dat zij zich in hun functioneren binnen dit ideaal blijven bewegen. Het recht op vrijheid van godsdienst en levensovertuiging is uiteindelijk ook ondergeschikt aan dit ideaal en kan alleen worden gehonoreerd voor zover het daar niet mee in strijd komt. Vorster daarentegen redeneert vanuit de mens. Deze is in zijn optiek een religieus wezen, dat alleen aan zijn bestemming kan voldoen indien hij zijn leven op zijn levensovertuiging baseert. Daartoe kan de mens niet slechts volstaan met zijn levensovertuiging privé vorm te geven, maar dit moet ook in het publieke domein gebeuren door deelname aan en steun voor levensbeschouwelijke organisaties. De staat, die als laatste aan bod komt (in het citaat zelfs niet bij name wordt genoemd), moet bovenal ruimte geven aan mensen die hun levensovertuiging gestalte willen geven in zowel het publieke als het privédomein. We zien hier dat de liberale democratie als het ware in dienst komt te staan van de vrijheid van godsdienst, die daarmee het karakter aanneemt van een natuurrecht, dat voorafgaat aan de staat. Pas wanneer we de essentie van het mens-zijn goed voor ogen hebben, kunnen we vervolgens nadenken over de vraag hoe we het constitutionalisme alsmede de democratie moeten vormgeven.

\section{Constitutionalisme}

Welke consequenties heeft de door Vorster voorgestane antropologie voor zijn visie op wat constitutionalisme precies inhoudt? Het is nauwelijks overdreven om te stellen dat de meeste binnen het (vergelijkende) constitutionele recht gangbare definities van constitutionalisme eerder aansluiten bij de benadering van Cohen dan bij die van Vorster. Dat geeft aan dat Cohen bepaald geen sektarische minderheidsopvatting vertolkt, maar eerder aansluit bij de mainstream opvattingen dienaangaande. Het nieuwe schuilt er dan eerder in dat zij er consequenties aan verbindt voor het recht op vrijheid van godsdienst en levensovertuiging. Dat Cohen aansluit bij de heersende leer betekent echter nog niet dat zij ook gelijk heeft. De vraag waarin zij geïnteresseerd is, luidt, overeenkomstig de titel van haar artikel: 'Whose Sovereignty?' Zij stelt de vraag bij wie de soevereiniteit berust en voor haar is het duidelijk dat dit bij de staat moet zijn. Alleen op die manier is het mogelijk haar visie op de liberale democratie te realiseren. Dit is echter wel enigszins paradoxaal. Constitutionalisme kan immers vrij worden omschreven als het 
geheel van staatsrechtelijke arrangementen dat erop gericht is om de rechten en vrijheden van de burgers tegenover de staat te waarborgen. Als het dan vervolgens zo is dat alle touwtjes uiteindelijk in handen van de staat worden gelegd, aangezien alleen op die manier het liberalisme kan worden gerealiseerd, wordt de liberale democratie eigenlijk belangrijker gemaakt dan de rechten en vrijheden van de burgers in wier naam het liberalisme wordt aangehangen. Is een volledige soevereiniteit van de staat welbeschouwd in het belang van de bescherming van de rechten en vrijheden van burgers?

De katholieke rechtswetenschapper Richard W. Garnett is enige jaren geleden met een alternatieve definitie van constitutionalisme gekomen, die het overwegen waard lijkt. In de visie van Garnett is constitutionalisme:

'the enterprise of protecting human freedom and promoting the common good by categorizing, separating, structuring, and limiting power in entrenched and enforceable ways' ${ }^{13}$

Op het eerste gezicht komt deze omschrijving behoorlijk in de buurt van standaardomschrijvingen van het principe van machtenscheiding, zoals ook Cohen dat zal omschrijven. Het is begrijpelijk dat de omschrijving van Garnett hier raakvlakken mee vertoont, aangezien de machtenscheiding de klassieke manier is om de rechten en vrijheden van burgers te beschermen, gegeven het feit dat er enigerlei vorm van staatsgezag nodig is. Het idee is dat het kan helpen om dat staatsgezag niet absoluut te laten zijn, maar het op te delen in verschillende onderdelen, die elkaar kunnen beteugelen en controleren. De vraag die hier echter speelt, is welke macht als uitgangspunt geldt.

Bij nadere beschouwing bevat Garnetts omschrijving van machtenscheiding een element dat in veel klassieke definities van constitutionalisme ontbreekt, te weten de bevordering van het algemeen welzijn. Garnett laat zich hier kennen als een katholieke auteur, want de notie van het algemeen welzijn neemt vanouds een belangrijke plaats in binnen de katholieke sociale leer. In het liberalisme daarentegen wordt er eerder van uitgegaan dat de staat onder alle omstandigheden neutraal dient te zijn en dat dit uitgangspunt eraan in de weg staat dat de staat zou trachten het algemeen welzijn te bevorderen. Hoe kan de staat immers bepalen wat het algemeen welzijn bevordert wanneer zijn neutraliteit het hoogste goed is? Neutraliteit neemt zo de plaats van algemeen welzijn over. Een vraag die de omschrijving van Garnett oproept, is of er binnen het liberale constitutionalisme niet toch ook meer ruimte kan en moet worden gemaakt voor de notie van het algemeen welzijn. Is het immers wel zo vanzelfsprekend dat het liberalisme in de praktijk uitmondt in een vrijwel volledig waardenrelativisme?

Het verschil tussen de opvattingen van Cohen en Garnett over constitutionalisme wordt nog duidelijker wanneer een toevoeging in aanmerking wordt genomen die 
Garnett aanbrengt bij zijn hiervoor weergegeven definitie. Garnett schrijft namelijk tevens dat:

'[c]onstitutionalism relies, both in theory and in fact, not only on the separation and limitation of the powers of the political authority, but also on the existence and the health of authorities and associations outside, and meaningfully independent of, the state'. ${ }^{14}$

Dit nu is een gevoelig element, want Garnett breidt hier de werking van het principe van machtenscheiding uit van staatsmachten tot organisaties van burgers die onafhankelijk zijn van de staat. Dit past echter niet goed binnen een doctrinaire opvatting van het staatsrecht, waarin dit recht alleen betrekking heeft op de staat en instituties die door publiekrecht in het leven zijn geroepen. Bovendien wordt hiermee de algehele soevereiniteit van de staat doorbroken en ontstaat een nieuwe constellatie waarin de soevereiniteit gedeeld wordt tussen de staat en van diezelfde staat onafhankelijke organisaties van de civil society. Zoals we hebben gezien, is dit precies waar Cohen zich zorgen over maakt.

Toch is het de vraag of het zo'n vreemde gedachte is om, zeker in de 21ste eeuw, het principe van machtenscheiding op deze manier uit te breiden. Door de opkomst van de sociale rechtsstaat is het aantal taken van de staat immers gegroeid. Het helpt dan niet meer voldoende om de staatsmacht op te delen in drie machten. Het is hiernaast noodzakelijk om tegenmacht in het leven te roepen tegen de staatsmacht als zodanig, ongeacht of het nu de wetgevende, de uitvoerende of de rechterlijke macht betreft. Door de opkomst van de sociale rechtsstaat is immers het verschil tussen de drie machten vervaagd, aangezien de uitvoerende macht ook aan wetgeving is gaan doen, terwijl de rechterlijke macht zich bij wijze van compensatie intensiever is gaan bezighouden met de controle van bestuurshandelen. Naast de opkomst van de sociale rechtsstaat heeft ook de internationalisering bijgedragen aan een versterking van de positie van het bestuur binnen de trias politica. De wetgever is onvoldoende in de gelegenheid controle uit te oefenen op een en ander, aangezien de besluitvorming zich voor een deel heeft verplaatst naar internationale gremia.

Afgezien van staatsrechtelijke overwegingen die voortvloeien uit de trias politica, sluit een uitbreiding van de omschrijving van constitutionalisme met maatschappelijke organisaties aan bij de in de vorige paragraaf uiteengezette mensvisie. Indien het immers zo is dat mensen alleen dan tot hun bestemming komen wanneer zij hun activiteiten zowel in het publieke als in het privédomein stoelen op hun geloof of andere levensovertuiging, dan moeten die activiteiten in het publieke domein ook zin kunnen hebben. 


\section{Democratie}

Bekijken we vervolgens de betekenis van de door Vorster voorgestane mensvisie voor de democratie, dan lijkt deze vooral goed aan te sluiten bij een visie op democratie waarin eenieder vrijuit politiek kan participeren. Dit zowel individueel als in groepsverband. Het laatste is van belang, omdat het niet eenvoudig is om als burger, zelfs indien men beschikt over een uitgewerkte levensbeschouwing, de vertaalslag te maken van persoonlijke naar politieke opvattingen. Hierbij zal dikwijls, op tenminste een aantal beleidsthema's, de hulp nodig zijn van deskundige geestverwanten. Van belang is dat iedere burger hiertoe op gelijke voet in de gelegenheid is, ongeacht geloof of levensovertuiging. De christelijke filosoof Nicholas Wolterstorff heeft een dergelijke visie op democratie aangeduid als 'equal political voice'-liberalisme. ${ }^{15}$ Hierbij beklemtoont hij overigens dat deze 'equal political voice' moet worden uitgeoefend binnen de grenzen van een geschreven of ongeschreven grondwet, die via de werking van een aantal klassieke rechten waarborgt dat burgers niet onevenredig in hun vrijheid worden aangetast door de uitoefening van 'equal political voice' door hun medeburgers.

Dit laatste vormt een verschil met de opvatting van 'public reason'-liberalisme zoals aangehangen door de, zeker in de Verenigde Staten, nog altijd invloedrijke filosoof John Rawls (1921-2002). ${ }^{16}$ Ook Rawls zal aanvaarden dat de uitoefening van 'political voice' aan constitutionele grenzen is gebonden. Hij formuleert echter aanvullende grenzen voortvloeiend uit het idee van publieke rede. Dit idee komt er kort gezegd op neer dat het politieke debat dient te worden gevoerd met argumenten die voor alle deelnemers navolgbaar zijn. Hoewel dit op het eerste gezicht een begrijpelijke eis lijkt, die aan alle deelnemers gelijkelijk gesteld wordt, bestaat er een risico dat gelovigen erdoor op achterstand worden gesteld. Voor zover zij immers een redenering zouden willen hanteren die rechtstreeks voortvloeit uit hun geloofsovertuiging, kunnen andere deelnemers aan het debat dit verhinderen door aan te voeren dat de redenering voor hen niet navolgbaar is. Indien gelovigen vervolgens hun redenering in 'neutrale' termen moeten formuleren, kunnen er allicht nuances verloren gaan. Bovendien komt deze opvatting voort uit het aanvechtbare idee dat alleen geloofsovertuigingen tot onnavolgbare redeneringen zouden leiden, terwijl seculiere redeneringen per definitie neutraal zouden zijn. Het is in reactie op dit liberalisme van de publieke rede dat Wolterstorff zijn variant van 'equal political voice'-liberalisme heeft geformuleerd.

Dit 'equal political voice'-liberalisme vormt tevens een contrast met een ander, op dit moment weer invloedrijk, verschijnsel, te weten dat van het populisme. Dit is niet de plaats om uit te weiden over de vraag wat populisme precies inhoudt. Hierover is inmiddels de nodige nieuwe literatuur beschikbaar. Binnen deze nieuwe literatuur neemt het boek What is Populism? van de aan de Universiteit van Princeton verbonden politicoloog Jan-Werner Müller een bijzondere plaats 
in. In zijn boek noemt Müller als een van de centrale kenmerken van populisme het 'antipluralisme'. ${ }^{17}$ Hiermee doelt Müller op het feit dat het populisme uitgaat van het idee dat er een volk bestaat dat zich gezamenlijk heeft te keren tegen hen vijandig gezinde elites. Niet alleen deze elites, maar ook diegenen die zich niet wensen aan te sluiten bij de door 'het volk' aangehangen meerderheidsopvatting, worden niet geacht tot het volk te behoren. In plaats van pluraal wordt het volk dus geacht een eenheid te vormen. Wie zich daarmee niet identificeert, zal niet in gelijke mate politiek kunnen participeren, zoals het 'equal political voice'-liberalisme verlangt.

Deze laatste opvatting gaat juist wel uit van pluralisme. ${ }^{18}$ Daarmee sluit deze vorm van liberalisme aan op de door Vorster geschetste mensvisie, waarin mensen spirituele wezens zijn, voor wie ruimte dient te worden gecreëerd om hun religie handen en voeten te geven in zowel het publieke als het privédomein. Dit brengt een verruiming van het begrip 'politiek' met zich mee, aangezien deze zich niet langer beperkt tot hetgeen in de politieke instituties gebeurt, maar zich tevens uitstrekt tot andere politieke activiteiten van burgers en hun organisaties. Deelname aan dergelijke organisaties is voor burgers noodzakelijk teneinde gevoed te worden in hun politieke overtuigingen. Op hun beurt dragen de organisaties van burgers bij aan de legitimiteit van het politieke bestel. Er wordt dus niet op voorhand getracht de potentiële onenigheid van burgers te neutraliseren, zoals het liberalisme van de publieke rede doet. De 'equal political voice'-variant van liberalisme gaat er integendeel van uit dat deze onenigheid de essentie vormt van politiek. Daarop dient te worden ingespeeld door een open en vrije 'global public square' in het leven te roepen. ${ }^{19}$ Zoals gezien, worden de grenzen hiervan slechts bepaald door de klassieke grondrechten uit de grondwet.

Hoogleraar Recht en Religie John Inazu heeft recentelijk een concrete uitwerking gegeven van de eisen waaraan een politiek stelsel moet voldoen om aan een 'equal political voice'-variant van liberalisme te voldoen. ${ }^{20}$ Op constitutioneel gebied betreft dit de eisen van het eerbiedigen van het hiervoor genoemde principe van 'freedom of the church', het faciliteren van publieke fora voor expressie, ook indien het minderheidsopvattingen betreft, en gelijke financiering van alle organisaties die aan politieke expressie doen. Deze laatste eis is omstreden, zowel in de Verenigde Staten als in toenemende mate in Europa. Toch heeft Inazu hier wel een punt, voor zover het niet gelijk behandelen van verschillende categorieën van levensbeschouwelijke organisaties opnieuw uitgaat van het aanvechtbare idee dat alleen levensbeschouwelijke organisaties een bepaalde ideologische kleur kennen terwijl seculiere organisaties neutraal zijn. Hiernaast zijn er aan de kant van de burgers ook bepaalde deugden nodig, zoals die van tolerantie, bescheidenheid en

18 Hetzelfde geldt overigens voor de opvatting van een 'argumentative democracy' van Rowan Williams. Zie diens Faith in the Public Square, Londen 2012, Kindle. ed., loc. 2551.

19 O. Guinness, The Global Public Square. Religious Freedom and the Making of a World Safe for Diversity, Downers Grove 2013.

20 J.D. Inazu, Confident Pluralism: Surviving and Thriving Through Deep Difference, Chicago 2016. 
geduld. Ik werk dit hier verder niet uit. Wel zij opgemerkt dat ook voor het aanleren en onderhouden van dergelijke deugden maatschappelijke organisaties weer goede diensten kunnen bewijzen.

\section{Godsdienstvrijheid}

We zijn, ten slotte, aanbeland bij de implicaties van de door Vorster verwoorde mensvisie voor de godsdienstvrijheid. Om deze implicaties duidelijk te maken sluit ik aan bij de theorie over godsdienstvrijheid van hoogleraar Constitutionele interpretatie aan de Universiteit van St. Thomas in Minnesota, Michael Stokes Paulsen. ${ }^{21}$ Deze theorie heet 'The Piority of God', waarmee Paulsen doelt op het feit dat godsdienstvrijheid alleen dan volledig kan worden gerealiseerd wanneer de staat uitgaat van het idee dat religieuze waarheid bestaat. Idealiter gaat dit idee gepaard met religieuze tolerantie. Wanneer een staat immers zelf zou vaststellen wat de religieuze waarheid inhoudt, verheft hij zich in feite boven God. De combinatie van erkenning van het bestaan van religieuze waarheid enerzijds en religieuze tolerantie anderzijds is kenmerkend voor de liberale visie op godsdienstvrijheid. Deze combinatie lag ten grondslag aan het Amerikaanse constitutionele bestel. In de situatie dat de staat niet religieus tolerant is, spreken we van een preliberale visie op godsdienstvrijheid. Voorafgaand aan de stichting van de Verenigde Staten was deze visie kenmerkend voor vele Europese stelsels. In andere delen van de wereld komt de preliberale visie op godsdienstvrijheid ook thans nog veelvuldig voor. De staatsrechtswetenschapper Ran Hirschl heeft de naam 'constitutionele theocratieën' bedacht voor dergelijke stelsels, waarvan Iran een voorbeeld vormt. ${ }^{22}$

Ook in het Westen is de liberale visie echter niet onverminderd meer van kracht. Paulsen wijst erop dat in de Verenigde Staten inmiddels eerder een moderne visie op godsdienstvrijheid wordt aangehangen. Deze moderne variant heeft het idee dat er religieuze waarheid bestaat achter zich gelaten. Dat leidt er niet direct toe dat ook de religieuze tolerantie verdwijnt. Hoewel gelovigen inmiddels als enigszins achtergebleven worden beschouwd, is het wel zo aardig om hen nog te blijven verdragen. Dit spoort ook het beste met het uitgangspunt van de individuele autonomie. Toch is aan de tolerantie wel een grens gesteld. Religieuze opvattingen moeten wel praktisch en redelijk blijven. Met het wegvallen van het idee dat er religieuze waarheid bestaat, is immers het onderscheid met andere opvattingen en uitingen verdwenen. Strikt genomen is daardoor de grond aan een recht op godsdienstvrijheid komen te ontvallen. Dat betekent dat zeker accommodatie van religieuze instituties controversieel wordt. Iedereen en elke organisatie dient zich tenslotte aan de wet te houden en het zou oneerlijk zijn om voor een bepaalde categorie personen of organisaties een uitzondering te maken op deze regel. Een voorbeeld waarin de Obama-regering de grenzen van de redelijkheid bereikt

21 M. Stokes Paulsen, 'The Priority of God: A Theory of Religious Liberty', Pepperdine Law Review 2013, 5, p. 1159-1222.

22 R. Hirschl, Constitutional Theocracy, Cambridge 2010. 
achtte, was de zaak van de Little Sisters of the Poor. Deze kloosterorde beschouwde de verplichte meeverzekering van abortus en contraceptiva onder Obamacare dermate belastend, dat zij er uiteindelijk mee bij het Amerikaanse Hooggerechtshof belandde.

Het kan echter nog verder verkeren voor wie de godsdienstvrijheid dierbaar is. Paulsen onderscheidt namelijk tevens een postmoderne visie op godsdienstvrijheid, waarin de staat het bestaan van religieuze waarheid niet langer erkent en eveneens niet langer tolerant is ten opzichte van religieuze organisaties. Deze situatie acht Paulsen mogelijkerwijze reeds aan de orde van de dag in Europa, bijvoorbeeld in een land als Frankrijk. Paradoxaal genoeg betekent deze variant tot op zekere hoogte een terugkeer naar de preliberale variant. Het verschil daarmee is dat de staat niet uitgaat van religieuze waarheid, maar van seculiere waarheid. Daarmee verwordt het op zichzelf legitieme secularisme feitelijk tot nieuwe staatsreligie. Dit staatssecularisme is intolerant jegens gelovigen en hun organisaties, aangezien deze een bedreiging vormen voor de gepercipieerde neutraliteit van de staat. Van godsdienstvrijheid is dan ook niet langer sprake.

Het moge duidelijk zijn dat de liberale visie op godsdienstvrijheid het beste aansluit op de door Vorster voorgestane mensvisie. Indien het zo is dat mensen van nature spirituele wezens zijn, die ruimte nodig hebben om hun leven te baseren op de door hen aangehangen levensbeschouwing, dan is de godsdienstvrijheid feitelijk een natuurrecht dat voorafgaat aan de staat. In de omgekeerde situatie betreft het een positief recht, dat in het leven geroepen is door de staat. Indien de staat een recht in het leven kan roepen, kan het dit ook beperken of zelfs weer intrekken. Feitelijk wordt het daarmee van de staat afhankelijk of mensen tot hun volledige bestemming komen. Dit is, zoals we eerder zagen, het geval in de situatie waarin Cohen haar zin zou krijgen. Haar visie op liberale democratie gaat immers voor, en mensen en hun organisaties zullen erop moeten toezien dat zij binnen de grenzen blijven die deze visie stelt teneinde volledig gerealiseerd te kunnen worden. In de visie die oorspronkelijk ten grondslag ligt aan het Amerikaanse staatsbestel zal omgekeerd de staat binnen de grenzen moeten blijven die het mensen mogelijk maakt om volledig tot hun bestemming te komen. Dat brengt met zich mee dat de staat de godsdienstvrijheid erkent als een natuurrecht dat voorafgaat aan zijn eigen bestaan, zodat de prioriteit aan God toekomt.

De overgang van een liberale naar een moderne, of zelfs een postmoderne, visie op godsdienstvrijheid stelt gelovigen voor een dilemma. Een mogelijkheid is dat zij zich genoodzaakt zien het liberalisme vaarwel te zeggen en zich in elk geval tijdelijk terug te trekken uit de actieve participatie in de samenleving. The Benedict Option is een inmiddels bekend geworden boek dat deze optie in het geval van christenen betrekt. ${ }^{23}$ Een andere mogelijkheid is dat gelovigen van binnenuit het liberalisme trachten te hervormen. Dat zal evenwel niet van vandaag op morgen kunnen. Net zomin als de verschuiving van liberalisme naar modernisme van de ene op de andere dag tot stand is gekomen, zal het ook mogelijk generaties duren 
voordat de weg terug is afgelegd. Wie deze optie wil trachten te realiseren, zal zijn hoop moeten vestigen op maatschappelijke instituties als de familie, de school en de kerk, synagoge of moskee. Daarvoor is dan echter wel een ruimhartige opvatting van godsdienstvrijheid vereist, die in een moderne of postmoderne visie op dit recht nu juist onder druk staat. Heel gemakkelijk te realiseren is deze optie dus evenmin. Voor zover het doel van de Benedictijnse optie is om te zijner tijd weer te gaan participeren in de samenleving, zal voor deze optie eveneens geruime tijd nodig zijn om haar te realiseren. De huidige situatie van de godsdienstvrijheid valt, kortom, in het Westen niet rooskleurig te noemen.

\section{Conclusie: een mooie horizon?}

De vraag is al met al gerechtvaardigd hoe realistisch de in deze bijdrage uiteengezette visie op constitutionalisme, democratie en godsdienstvrijheid is. Wanneer de staat niet langer uitgaat van het bestaan van religieuze waarheid, dan is de mensvisie van Vorster de facto losgelaten en kan deze bezwaarlijk nog langer het constitutionalisme en de democratie beïnvloeden. We zijn dan in een moderne of zelfs postmoderne constellatie beland, waarin de visie van Cohen op geloof in de liberale democratie de overhand krijgt. Hoewel deze taxatie min of meer logisch voortvloeit uit het voorgaande, dient toch gewaakt te worden voor overdrijving. De eerste reden daarvoor is dat het, vergeleken met andere delen van de wereld, nog altijd relatief goed gesteld is met de godsdienstvrijheid in het Westen. Ook wanneer we de blik beperken tot ons deel van de wereld, kan de situatie zowel van land tot land als in de tijd verschillen. Indien bijvoorbeeld enkele Europese landen zijn opgeschoven richting een postmoderne visie op godsdienstvrijheid, hoeft dat nog niet over de hele linie te gelden. In het geval een moderne visie op godsdienstvrijheid wordt aangehangen, zijn er nog altijd meer raakvlakken met de liberale uitgangssituatie dan in een postmoderne constellatie het geval is.

Wie een appèl wil doen tot verandering, kan beter de positieve kanten van het alternatief beklemtonen dan de negatieve kanten van de status quo. Ook dit is een reden om de ernst van de huidige situatie niet te overdrijven. ${ }^{24}$ In een andere context heeft paus Franciscus gewezen op de aantrekkingskracht die kan uitgaan van het delen van 'vreugde' en het wijzen op een 'mooie horizon' ${ }^{25}$ Het is in deze geest dat hiervoor aandacht is gevraagd voor een alternatief voor de visie van Cohen en andere nieuwe critici van het recht op godsdienstvrijheid en levensovertuiging op geloof in de liberale democratie. Een visie die de mens en de menselijke ervaring als vertrekpunt kiest en van daaruit het constitutionele en politieke stelsel ontwerpt, is niet alleen historisch meer in overeenstemming met hoe westerse stelsels zijn vormgegeven, maar ook in het heden potentieel nog attractiever dan de tegenovergestelde werkwijze. Het geloof in de liberale democratie kan erdoor worden versterkt. In de tegenovergestelde situatie wordt eerst door politieke the- 
oretici een inhoudelijke visie op liberale democratie ontworpen. Teneinde deze visie aan de maatschappelijke werkelijkheid op te kunnen leggen, wordt van mensen en hun organisaties verlangd dat zij zich hiernaar voegen. Welbeschouwd is deze visie even antipluralistisch als het populisme. Wie zich niet wenst te schikken naar de aan de liberale democratie gestelde inhoudelijke eisen, hoort niet langer bij het volk en wordt daarvan uitgesloten. Hierdoor dreigt op termijn ook het geloof in de liberale democratie te verminderen.

Het beroep op theologische concepten als vreugde en schoonheid laat tevens de waarde van een interdisciplinaire benadering van het constitutionele recht in het algemeen en van samenwerking met de theologie in het bijzonder zien. Het recht bevat zelf zeker ook normatieve begrippen, zoals rechtvaardigheid, die het positieve recht kunnen sturen. In de praktijk blijkt deze sturende kracht echter gering. Wanneer het begrip rechtvaardigheid door de nieuwe critici van godsdienstvrijheid wordt gebezigd, blijkt het tot tegengestelde resultaten te leiden dan dit artikel bepleit. Er valt daarom niet aan te ontkomen om nog een spade dieper te steken en te beginnen met de vraag wie de mens eigenlijk is. Zo is dat ook in de periode van de stichting van de Verenigde Staten bewust of onbewust gebeurd. Voor zover het pleidooi voor een eerherstel van klassiek-liberale waarden een terugkeer behelst naar een aantal centrale gedachten aangaande de staatsinrichting zoals in deze periode ontwikkeld, verdient het aanbeveling de rol van antropologie wederom niet te veronachtzamen. Daarbij kunnen andere disciplines, zoals de ethiek en de theologie, de rechtswetenschap goede diensten bewijzen. 